\title{
Impact of Promotion on Students' Enrollment: A Case of Private Schools in Pakistan
}

\author{
Shahid Nawaz Khan \\ $\mathrm{PhD}$ Scholar, Faculty of Management Sciences, International Islamic University \\ Islamabad, Pakistan \\ Tel: 92-300-979-0119Ｅ-mail: 9790119@gmail.com
}

Imran M. Qureshi

Assistant Professor, Faculty of Management Sciences, International Islamic University

Islamabad, Pakistan

Tel: 92-342-511-1177 E-mail: i_m_q@iiu.edu.pk

\begin{abstract}
Purpose - This study is designed to explore the variables that have a strong impact on students' enrollment in private schools and by the optimal use of these promotional variables private schools attract students for enrollment.

Design/methodology/approach - The study is qualitative and exploratory in nature, since the aim was to explore the principals/administrators' views and experiences about promotional variables within the education sector in Pakistan. Data was collected by carrying out in-depth qualitative interviews with school principals/administrators in 16 schools of two neighboring cities namely Islamabad and Rawalpindi (Pakistan). The qualitative data was analyzed and presented in a tabulated and descriptive form.
\end{abstract}

Findings - The analysis revealed four variables of promotion namely: school appearance, public relations, publicity, and advertisement (print and electronic media). These four variables were found to be the main forms of promotion used by private schools for recruiting students. There was also a strong impact of school appearance being used as the standard tool for promotion.

Research limitations/implications - The study focused on one sector, the education sector in Pakistan. In order to enhance one's understanding and knowledge regarding the promotional variables. This needs to be taken into consideration in generalizing the findings to other sectors and geographic markets. The study is also limited to only two cities in Pakistan. Although these cities are highly representative of other cities in Pakistan but there are certain regional idiosyncrasies that can have varying impacts.

Practical implications - This exploratory study establishes the forms of promotion that are used by most schools in Pakistan. School administrations can look at this study and further explore the link between recruitment and types of promotion. This study can also help promotional companies to develop service packages for the education sector in Pakistan.

Originality/value - How private schools attract and influence students for enrollment and what are the sources for that influences and attraction, is not an actively researched topic in Pakistan. The study would therefore contribute towards better understanding of promotional variables and designing of effective promotional strategies.

Keywords: Promotion, School appearance, Public Relations, Advertisement, Publicity, Islamabad, Rawalpindi, Pakistan

Paper type: Exploratory Research

\section{Introduction}

Education leads the whole society towards civilization and sophistication. It is education which fosters innovation and renders peace in the whole society. It inculcates in human beings better attitudes, behaviors and cognition and distinguishes them from other creatures on the basis of these attributes. Basically, it focuses on the individual's growth and development in society. Without recognizing the importance of schools in the society, the recognition of importance of education would be incomplete. As education is inter-related with individuals' growth and development in the society, in the same way schools are inter-related with education, due to this 
reason schools play a key role in spreading the light of education throughout society (Wolcott, 1983). Parents are always on the lookout for good schools that can provide the best education to their children. In order to attract students schools are also on the lookout for creating awareness about their institutions.

For individuals' awareness and perception, the education providers/schools proprietors are in need of good promotional strategies that can enhance the reputation of their schools. But the question is which promotional activities can be used to promote quality-oriented education in the society? This question becomes even more pertinent when the major proportion of the schooling system of a country is in the hands of the private sector. Marketing of services especially education marketing has dramatically advanced from the previous ten years. The marketing plans focus on both students and institutional needs (Russell, 2005).

The schools are the best places which provide an educational environment in the formal way. A school being a social system has all parts being interdependent. Creating changes in one part would reflect changes in other parts as well (Pinnell, 1985). To bring quality of education in the existing educational environment, it is crucial to enhance the competition within private schools so that the quality of education is enhanced. Due to the increased competition, the schools will enhance the quality of their main service "education" and for that purpose, they will use better promotional activities to attract students for enrollment. Since this rivalry requires designing programs and selling them to parents or students to enhance enrollments, educators around the world now attend special seminars and conferences to give them direction and supervision in the marketing of education (Rotfeld, 1999). Increased competition and promotional activities would serve as a check upon the school's performance. Consequently, the whole environment will be supportive for quality education and ultimately the whole nation would benefit from it.

The main idea of this research has been taken from Oplatka \& Brown (2004) from their research paper titled "Research on School Marketing". In this current research, the authors have sought to investigate the relationship between promotional variables and students' enrollment in private schools within Pakistani context. Which promotional antecedents, for example School Appearance, Public Relations, Publicity, Electronic and Print Media Advertisement affect and attract students for enrollment in private schools.

The key purpose of this research is to critically examine and test the relationship between promotional activities and students' enrollment in private schools in the context of a developing country. The objectives of the research are:

a) To explore, study and critically evaluate the characteristics, role and impact of promotion on students' enrollment.

b) To study and examine the impact of promotion on how private schools attract students for admission.

c) To study and examine how private schools use "Promotion" for gaining competitive advantage.

Very little is researched about the rapidly growing business of private schools in a developing country context. The contribution of this study to the literature will be multi-fold. Firstly, the study will demonstrate the perception of students about quality education and assess the factors that contribute more on changing their perception. Secondly, it will provide the impact of promotion on students' enrollment especially in Pakistani context.

This study will help to understand the role of promotion in developing and promoting a private school in a society. Further to understand and implement the better use of this marketing tool "Promotion" in the private schools competitive environment where many schools are offering the same service "Education" but with the use of different promotional techniques. This study will further contribute to the policy makers to take corrective measures and restrict the private schools from negative promotion that might harm any part of education otherwise it will disturb and harm the whole interdependent system of education.

\section{Literature Review}

The promotional activities of schools include activities such as advertisements, Public Relations, written materials and so forth. Conversely, the client's need-based product development and improvement in the schools accessibility and availability lacks in the schools (Kotler \& Armstrong, 1999). The company gives priority to customer's needs in designing the products or services (Kohli \& Jawarski, 1990). According to Woods (1993), the adoption by schools of "market orientation" in most of the countries is restricted by governmental legislations. As per Herbert (2000) some Welsh principals promoted their schools by getting the parent's favor through some special language units. Some schools focused on their extra curricular activities, clubs, music and performing arts (Bell, 1999). Without adoption of marketing culture and orientation into schools and the positive 
response to the parents' needs in competitive educational environment, most of the schools will lose expected students (Oplatka \& Brown, 2004).

The purpose of "Promotion" of an educational institute is to make sure that either its primary and secondary beneficiaries as well as the distant stakeholder, that is the government, have understood and appreciated its work or not (Davies \& Ellison, 1999). Promotion consists of the elements of advertising, publicity and Public Relations. For different type of publics, different elements of promotion are being used, merely prospectus and websites do not replete the gap. From the schools point of view, especially for private schools, one of the most important activities in the year is to attract prospective students. The schools usually target prospective students using different promotional tools, such as, education exhibitions, open days, conventions, direct mail and advertising and so forth. There are the few tools which are used to attract the prospective students for recruitment towards institutions. Schools marketing communication (Promotion) is divided into two areas; one is traditional media promotion which includes advertising, publicity and electronic media. The second is direct mail promotion, which include prospectus and brochures (Ivy, 2008).

\section{School's Appearance}

Accessibility of the schools to the potential customers is not in practice and common in the schooling industry. Rather, school decoration plays an important role in its marketing efforts as did the Israeli principal (Oplatka, 2002 A). In England, the school management improved the facilities and decorated its entrance (Bell, 1999).

In some English schools, the children's creative work had been displayed over the notice board in the main entrance area and they used to change it regularly (Furse, 1989). Special projects such as school decoration and extra curricular activities are very crucial for giving the community, perception of good school discipline and of high achievement. Extra curricular activities usually, increase the students self-esteem, create feelings of loyalty and belongingness to the school and these are important parts of their learning self-discipline (Pinnell, 1985).

\section{Public Relations}

The period around 1988-1994 is considered the "Educational Marketisation" era. During this era, the term Public Relations became much discredited and disliked and even most of the organizations totally ignored this term. Most of the authors, due to its misusages ignored the term Public Relations and considered it a threat for the current practices and some suggested replacing the term by something more "school friendly" as "External Relations" which focused on good relations with all public that might not be used for just commercial ideas (Bunnell, 2005). The term Public Relations in schools is used for selling purpose rather than product improvement. For this reason, it has been criticized by Tyther (1992).

Public Relations faced an intense criticism and resistance before early 1990s and now, it has entered into the second phase of "Post-Marketisation". The periodicals inside educational marketing started in 1999 in UK. This phase was basically the expansion phase and the school managers started from a zero base with no prior knowledge, concerning this Public Relations term. Prior to 1990, Public Relations were considered the job of all employees rather than a specific trained practitioner. Public Relations were not effective and successful because of lack of funds and time but not due to lack of training or qualification (Bunnell, 2005). Foskett (1992) argued that the consideration regarding the term Public Relations in schools, was due to the lack of expertise and lack of specialist trainings. Further, Foskett (1994) explained that it had been ignored in the past as little attention had been given to it and still it is considered that this skill can easily and cheaply be acquired by the school managers. Oplatka (2002, A) quoted a principal who said that her "Aim (in the open evening) is to describe what is going on inside the school, in order to let parents choose to use reliable information instead of gossip". Schools greatly emphasized on Public Relations, in order to obtain media exposure and publicity instead of paid advertisements. Schools marketing policies largely depend on press coverage to their activities that will ultimately promote their brand name and image. Thus they may be in a position to attract prospective students (Oplatka \& Brown, 2003).

Bell (1999) said that most English principals advertise their school's events in the press to position their school in the local community. Furse (1989) indicated that many schools, through their good work publicizing by press, make good relationships with the local media. Goldring \& Rallis (1993) said that most dynamic school principals considered press as an environmental management strategy. They recognized the fact that good Public Relations have strong influences on parental judgments of local schools.

\section{Publicity}

Many people think about publicity as mere advertising, a propaganda, a deception misleading the public. Therefore, in context of educational publicity it should be defined clearly. The purpose of publicity and Public 
Relations, from an educational institute's point of view, is to keep the public in touch with the institution (Hyde, 1936). According to Elliott (1932) that once he heard the college president saying that his institution had never considered it necessary to do formal publicity. But, the very next day that college opened three well-organized offices of publicity with an operating budget of \$60,000 annually. (Bell, 1999; James \& Philips, 1995; Oplatka, 2002 A) said that publicity, the element of PR, is more preferable in schools instead of paid advertisements in local media. A brochure, which is the element of advertising, is wide spread in schools (Bell, 1999). Brochures were described as simple, attractive and easy to understand. It plays a crucial role in the school's marketing and is less costly as compared to the other type of advertisements. Ball (1994) quoted an English school female principal who said that "We are having a glossy prospectus next year (and) we are actually no longer having a home grown prospectus".

Hesketh \& Knight (1998) have argued that the development of prospectus has become more professional oriented since, 1991. They analyzed 52 brochures and in all the brochures different visual materials had been used and even 11 brochures were full of colors. The content and the message of the brochures include the name of the principal, his/her messages, its location and accessibility, its history, calendars, admission policies, the curriculum, teaching methods, aggregate result for final exams, social life in school, school facilities and discipline policy. The main focus is on the competitive advantage the school has on other schools (Copeland, 1994; Symes, 1998; Hesketh \& Knight, 1998; Oplatka, 2002 B).

Woods et al., (1996) said that secondary schools maintain good PR with their feeder elementary schools and it is the part of the promotional activities of the secondary schools, to attract the prospective students. For that purpose, the secondary schools give opportunities to the elementary schools, to use their facilities. According to Burnley (1998), "Publicity is a major tool of "Proactive Public Relations". In other words, it is offensively-rather than defensively-oriented and opportunity seeking rather than problem solving. Like advertising and personal selling, the fundamental purpose of marketing-oriented publicity is to create brand awareness, enhance attitudes towards a company and its brands and possibly influence purchase behavior. Companies obtain publicity using various forms of news releases, press conferences and other information dissemination. News releases concerning new products, modification in old products and other news-worthy topics are delivered to editors of newspapers, magazines and other media. Press conferences announce major news events of interest to the public. Photographs, tapes and films are useful for illustrating product improvements, new products and advanced production techniques".

\section{Advertisement (Electronic and Print Media)}

Moriarty (1991) (as cited by Speck \& Elliott, 1997) A customer is exposed to more than 3000 commercial messages in a typical week. Speck and Elliott (1997) mentioned four media sources (2-Electronic and 2-Print media sources) and the factors of their avoidance. Mostly the people, who have high income, small household perceive the magazines ads boring, unappealing, un-useful and hard to believe. It usually creates hurdles in locating other interesting things in the magazines. While the old people, with high education and income, recognize the newspapers positively but they don't like newspaper's ads. They consider it as uninteresting, un-useful and the number of newspaper's ads excessive and unnecessary. It diverts their attention from other newspaper's content. Young and high income people usually avoid TV commercials as they perceive it disturbing, unbelievable and a waste of time. It deters their search for other programming because people in this age group are usually more interested in watching too many channels. And the radio listeners who are young and un-married, they listen to too many stations and do not pay attention to radio commercials rather considering them irritating, bothersome and just waste of time. Yamamoto (2006) examined that TV plays a crucial role in influencing the students towards selecting an educational institution for admission purpose in Turkey.

\section{Theoretical Framework}

In this study, the effects of promotion on students' enrollment in private schools, has been investigated. It is done by hypothesizing a dependent and independent relationship between variables, in which promotion is taken as dependent variable while students' enrollment has been taken as independent variable. Further the dependent variable "Promotion" has been explored for some of its antecedents for example school appearance decoration, publicity, Public Relations, electronic media and print media advertisement.

\section{Hypothesis:}

In this study, on the basis of the previous literature, we have framed the following hypothesis.

H1: School's Appearance has a strong positive effect on students' enrollment in private schools.

H2: Public Relations is positively associated with students' enrollment in private schools. 
H3: Publicity has positive effect on students' enrollment in private schools.

H4: Advertisement (Electronic \& Print Media Advertisements) is strongly associated with students' enrollment in private schools

Schematic Diagram of Theoretical Framework

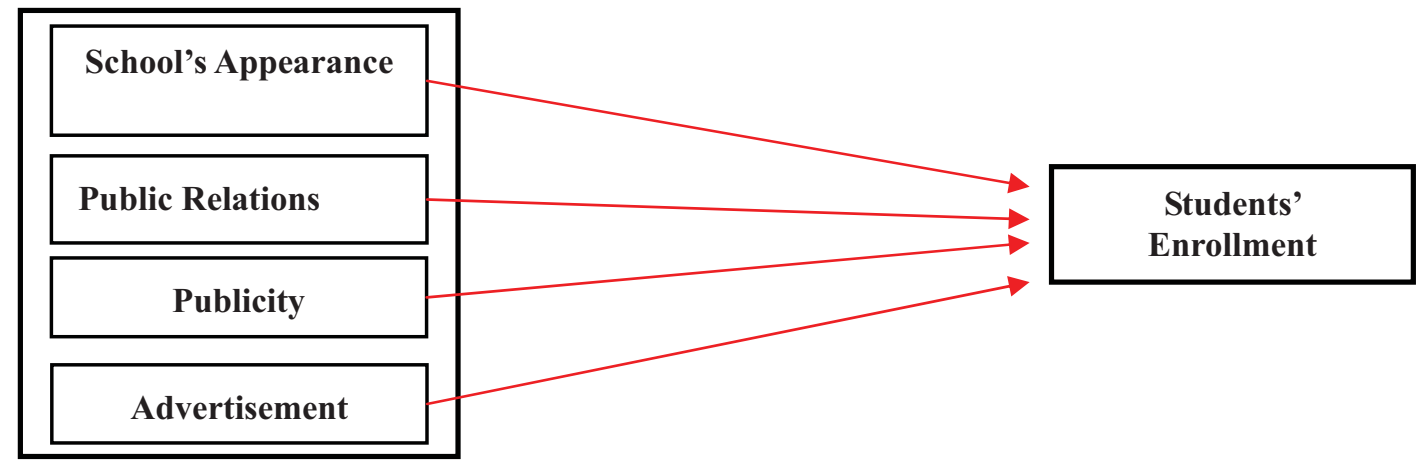

\section{Research methodology}

The study was qualitative in nature since its main aim was to explore the impact of different promotional variables on students' enrollment in private schools of two neighboring cities of Pakistan namely Islamabad and Rawalpindi. Student's numbers in the schools range from 245 to 2091. Data was generated mainly via in-depth qualitative face to face interviews with each principles/administrators, often in the principal/administrator's office. To avoid inter tensions and to encourage genuine information transference the interviews were not recorded, but field notes were undertaken. The interviews were semi-structured and lasted approximately half an hour on average. They were based on an interview guide (see Table I), which provided a focus on the issues and the direction that the inquiry aimed to follow. The guide was however followed with flexibility and simplicity. A total sample size was 20 private schools on a simple random basis but only 16 private schools took part in the study representing two neighboring cities of Pakistan namely Islamabad and Rawalpindi. The sample was equivalent to 100 per cent of the total number of private schools operating in the Islamabad but due to the reason that many of the private schools did not cooperate in interviews that's why the author has conducted the interviews in Rawalpindi city as well, to fulfill the criteria of the sample size that has been prior mentioned. The exploratory research approach was adopted because of its strength to reveal rich and in-depth data, which was essential in order to understand the concept and variables of "promotion" as applied by a specific sector of the services industry.

\section{Analysis}

To analyze the interview data, the authors first transposed the data collection and field notes into text. Then it was reorganized to give a consistent flow and structure for easy reference and analysis. Tables and figures were later designed to allow for comparison. Total 16 private schools ( 7 schools from Islamabad and 9 schools from Rawalpindi) participated in this study. Data for the previous five years from 2004 to 2008 has been collected for this purpose. Nine schools (6 schools from Islamabad and 3 schools from Rawalpindi) provided complete and appropriate data while remaining seven schools ( 1 school from Islamabad and 6 from Rawalpindi) provided partial data. None of the schools had a separate marketing department. In six schools all the school marketing activities were operated by the principal while, in ten schools there were administrators who were in-charge of the marketing activities. Table II represent the affects of promotional variables on avg. percentage increase of students' enrollment in private schools.

Table II lists all the types of promotion used by the schools between 2004 and 2008 and the percentage increase in the enrollments. Before proceeding further it must be made clear that this study only used the effect of promotion, other variables were not considered but from anecdotal evidence it can be safely assumed that promotional tools are one of the key reasons in increasing student enrollment. In this sample of sixteen schools, all of the schools used print media advertisements to attract students for enrollment and it had a strongly positive effect on students' enrollment. On the other hand electronic media had been used by $44 \%$ of the schools and the remaining 56\% schools did not use this promotional variable to attract students. Public Relations had been used by $94 \%$ of the schools as it had strong effects on students' enrollment. About $62.5 \%$ of the schools used publicity to attract students for enrollment while, $37.5 \%$ of the schools did not use this technique. It had positive but not highly significant effect on students' enrollment in private schools. School appearance has a strong effect on 
students' enrollment because $94 \%$ of the schools used this promotional technique to attract students for enrollment. In terms of marketing budget it is observed that over the years the median marketing expense has been increasing, this can be attributed to increasing inflation experienced in the country. Another interesting fact is that none of the schools have an established marketing department although the student strength has shown a steady rise.

\section{Conclusion}

This paper proposed that in the today's educational environment, it is crucial to implement promotional strategies to enhance peoples' awareness about education and the role of private schools in society. All the promotional tools/techniques have strong effects on students' enrollment but these can be used as per the environment and situation. Different promotional activities and variables have been used to test the affects of these variables on student's enrollment in private schools. For this purpose the authors have collected data for the last five years from 2004 to 2008, from 16 schools as to explore the effects of key promotional variables on the students' enrollment. Most of schools give importance to print media advertisement and school appearance while the other variables have also significant effect on students' enrollment. There can be many other reasons like prior reputation or failure of rival institutions that can result in increase in student enrollment but this study has reaffirmed that promotional tools in general are considered a key part of any strategy to attract prospective students to enroll in private schools.

\section{References}

Ball, S.J. (1994). Education Reform: A Critical and Post-Structural Approach. Open University Press, Buckingham.

Bell, L. (1999). "Primary schools and the nature of the education market place", in Bush, T., Bell, L., Bolam, R., Glatter, R. and Ribbins, P. (Eds), Educational Management: Redefining Theory, Policy, Practice, Paul Chapman, London, pp. 59-75.

Copeland, I.C. (1994). The primary school brochure: a sample analysis. Educational Studies, Vol. 20 No. 3, pp. 387-98.

Davies, B., \& Ellison, L. (1999). Strategic Direction and Devleopment of the School. Routledge, London.

Foskett, N. (1992). Managing External Relations in Schools. Routledge, London.

Frank R. Elliott. (1932). Publicity for Education. The Journal of Higher Education, Vol. 3, No. 6, pp. 303-308

Furse, J. (1989). Marketing in primary school, in Fidler, B. and Bowles, G. (Eds), Effective Local Management of Schools, Longman, London.

Gay Su Pinnell. (1985). The "Catch-22" of School Discipline Policy Making. Theory into Practice, Vol. 24, No. 4, Teaching Self-Discipline, pp. 286- 292

Goldring, E.B., and Rallis, S. (1993). Principals of Dynamic Schools. Corwin and Sage, Newbury Park, CA.

Gonca Telli Yamamoto. (2006). University evaluation-selection: a Turkish case. International Journal of Educational Management, Vol. 20, No. 7, pp. 559-569.

Herbert, D. (2000). School choice in the local environment: head-teachers as gatekeepers on an uneven playing field. School Leadership and Management, Vol. 20 No. 1, pp. 79-97.

Herbert Jack Rotfeld. (1999). Misplaced marketing, When marketing misplaces the benefits of Education. Journal of Education Marketing, VOL. 16, NO. 5, 1999, pp. 415-417.

Harry F. Wolcott. (1983). Adequate Schools and Inadequate Education: The Life History of a Sneaky Kid. Anthropology \& Education Quarterly, Vol. 14, No. 1, pp. 3-32

Hesketh, A.J., and Knight, P.T. (1998). Secondary school prospectuses and educational markets. Cambridge, Journal of Education, Vol. 28 No. 1, pp. 21-35.

Izhar Oplatka \& Jane Hemsley-Brown. (2004). Journal of Educational Administration, Vol. 42 No. 3, pp. $375-400$

James, C., and Phillips, P. (1995). The practice of educational marketing in schools. Educational Management and Administration, Vol. 23 No. 2, pp. 75-88.

Jonathan Ivy. (2008). A new higher education marketing mix: the 7Ps for MBA marketing. International Journal of Educational Management, Vol. 22 No. 4, pp. 288-299 
Kohli, A.K., and Jaworski, B.J. (1990). Market orientation: the construct, research propositions, and managerial implications. Journal of Marketing, Vol. 54, pp. 1-18.

Kotler, P., and Armstrong, G. (1999). Principles of Marketing. Prentice-Hall, Englewood cliffs, NJ.

Lovelock, C., and Weinberg, C. (1992). Public and Nonprofit Marketing, Boyd and Fraser.

Marilyn Russell. (2005). Marketing education, A review of service quality perceptions among international students. International Journal of Contemporary Hospitality Management, Vol. 17 No. 1, pp. 65-77.

Melvin W. Hyde. (1936). Educational Publicity. The Journal of Higher Education, Vol. 7, No. 3, pp. 134-137

Oplatka, I. (2002a). The emergence of educational marketing: lessons from the experiences of Israeli principals. Comparative Education Review, Vol. 46 No. 2, pp. 211-33.

Oplatka, I. (2002b). Secondary school brochures: what they tell us about diversity in a local educational arena. Education and Society, Vol. 20 No. 3, pp. 45-60.

Paul Surgi Speck and Michael T. Elliott. (1997). Predictors of Advertising Avoidance in Print and Broadcast Media. Journal of Advertising, Vol. 26, No. 3, pp. 61-76

Rosemary Burnley. (1998). International publicity: concepts and applications. Marketing Intelligence \& Planning, 16/2 107-113

Symes, C. (1998). Education for sale: a semiotic analysis of school prospectuses and other forms of educational marketing. Australian Journal of Education, Vol. 42 No. 2, pp. 133-52.

Tristan Bunnell. (2005). Strategic marketing planning in international schools. International Journal of Educational Management, Vol. 19 No. 1, pp. 59-66

Tyther, K. (1992). Marketing for the wrong reasons. Times Educational Supplement, 20 October, p. 12.

Woods, P. (1993). Responding to the consumer: parental choice and school effectiveness. School Effectiveness and School Improvement, Vol. 4 No. 3, pp. 205-29.

Woods, P., Bagley, C., and Glatter, R. (1996). Dynamics of competition - the effects of local competitive arenas on schools, in Pole, C. and Chawla-Duggan, R. (Eds), Reshaping Education in the 1990s: Perspectives on Secondary Education. Falmer Press, London.

Table I. Interview Questions

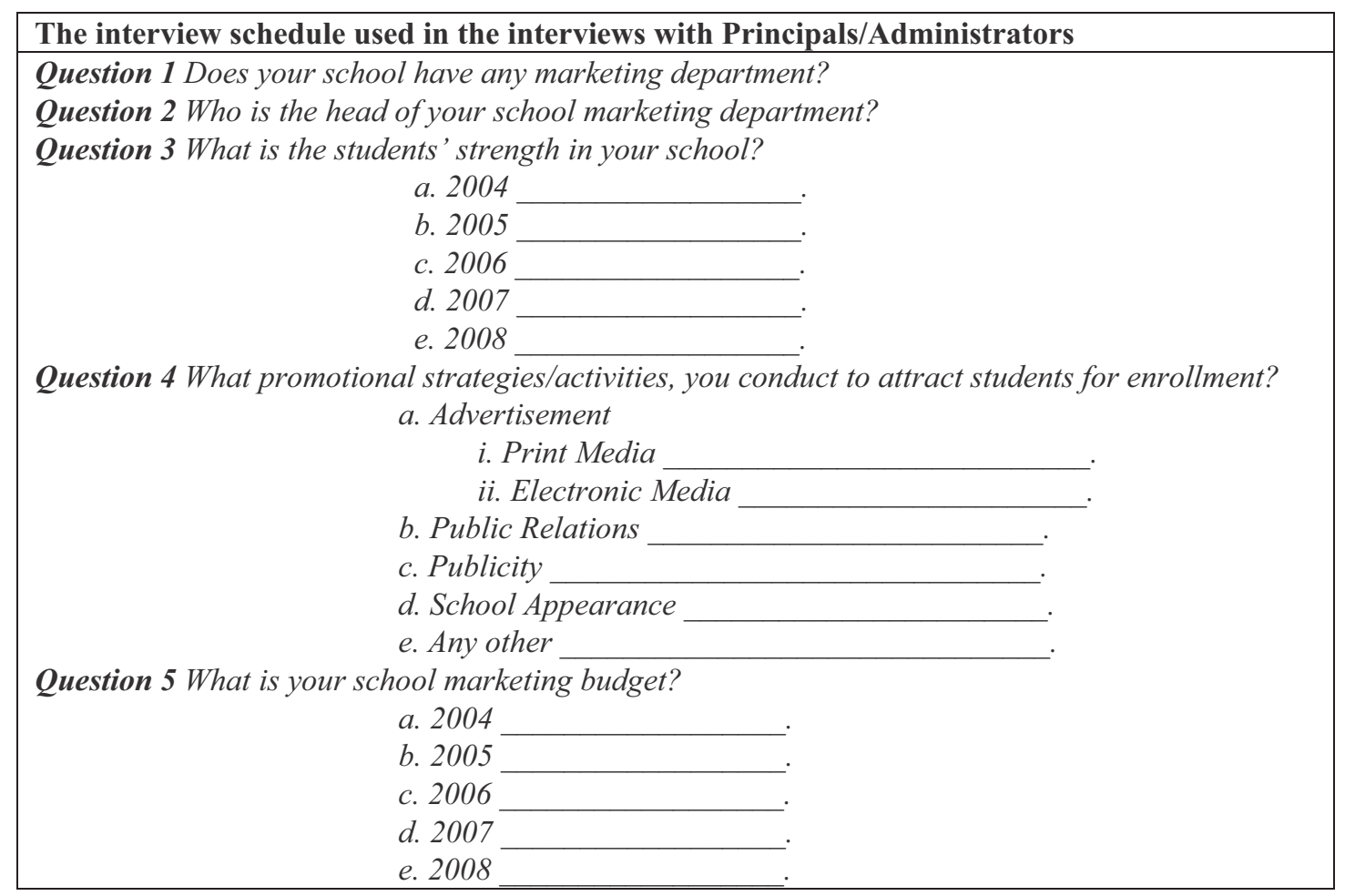


Table II. A tabulated presentation of affect of promotional variables on Avg. Percentage increase in students' enrollment

\begin{tabular}{|c|c|c|c|c|c|c|c|}
\hline \multirow{2}{*}{$\begin{array}{l}\text { S/No. } \\
\text { of } \\
\text { School } \\
\text { S }\end{array}$} & Advertisement & \multirow[t]{2}{*}{$\begin{array}{l}\text { Public } \\
\text { Relations } \\
\end{array}$} & \multirow[b]{2}{*}{ Publicity } & \multirow{2}{*}{$\begin{array}{l}\text { School } \\
\text { Appearanc } \\
\text { e }\end{array}$} & \multirow{2}{*}{$\begin{array}{l}\text { Avg. } \\
\text { Promotion } \\
\text { al } \\
\text { Expenses }\end{array}$} & \multirow{2}{*}{$\begin{array}{l}\text { Avg. \%in } \\
\text { crease in } \\
\text { students' } \\
\text { enrollme } \\
\text { nt }\end{array}$} & \multirow[b]{2}{*}{$\begin{array}{l}\text { Electroni } \\
\text { Media }\end{array}$} \\
\hline & $\begin{array}{lr}\text { Print } & \text { Media } \\
\text { (Pamphlets } & \& \\
\text { Banners) } & \\
\end{array}$ & & & & & & \\
\hline 1 & $\sqrt{ }$ & $\mathrm{X}$ & $\sqrt{ }$ & $\mathrm{X}$ & $\sqrt{ }$ & $0.061 \mathrm{M}$ & $15.00 \%$ \\
\hline 2 & $\sqrt{ }$ & $X$ & $\sqrt{ }$ & $\mathrm{X}$ & $\sqrt{ }$ & $0.122 \mathrm{M}$ & $11.00 \%$ \\
\hline 3 & $\sqrt{ }$ & $\mathrm{X}$ & $\sqrt{ }$ & $\mathrm{X}$ & $\sqrt{ }$ & $0.05 \mathrm{M}$ & $06.50 \%$ \\
\hline 4 & $\sqrt{ }$ & $\mathrm{X}$ & $\sqrt{ }$ & $\mathrm{X}$ & $\sqrt{ }$ & $0.15 \mathrm{M}$ & $18.50 \%$ \\
\hline 5 & $\sqrt{ }$ & $\sqrt{ }$ & $\sqrt{ }$ & $\sqrt{ }$ & $\sqrt{ }$ & $0.4 \mathrm{M}$ & $21.00 \%$ \\
\hline 6 & $\sqrt{ }$ & $X$ & $\sqrt{ }$ & $\sqrt{ }$ & $\sqrt{ }$ & $0.356 \mathrm{M}$ & $10.75 \%$ \\
\hline 7 & $\sqrt{ }$ & $\sqrt{ }$ & $\sqrt{ }$ & $\sqrt{ }$ & $\sqrt{ }$ & $0.104 \mathrm{M}$ & $08.00 \%$ \\
\hline 8 & $\sqrt{ }$ & $\sqrt{ }$ & $\sqrt{ }$ & $\sqrt{ }$ & $\sqrt{ }$ & $0.242 \mathrm{M}$ & $23.50 \%$ \\
\hline 9 & $\sqrt{ }$ & $\sqrt{ }$ & $\sqrt{ }$ & $\sqrt{ }$ & $\sqrt{ }$ & $0.3 \mathrm{M}$ & $15.75 \%$ \\
\hline 10 & $\sqrt{ }$ & $X$ & $\sqrt{ }$ & $\sqrt{ }$ & $\sqrt{ }$ & $1.00 \mathrm{M}$ & $15.00 \%$ \\
\hline 11 & $\sqrt{ }$ & $\sqrt{ }$ & $\sqrt{ }$ & $\sqrt{ }$ & $\sqrt{ }$ & $0.1 \mathrm{M}$ & $08.75 \%$ \\
\hline 12 & $\sqrt{ }$ & $\sqrt{ }$ & $\sqrt{ }$ & $\sqrt{ }$ & $\sqrt{ }$ & $0.262 \mathrm{M}$ & $10.25 \%$ \\
\hline 13 & $\sqrt{ }$ & $X$ & $\sqrt{ }$ & $\sqrt{ }$ & $\sqrt{ }$ & $0.288 \mathrm{M}$ & $06.00 \%$ \\
\hline 14 & $\sqrt{ }$ & $X$ & $X$ & $\mathrm{X}$ & $\mathrm{X}$ & $0.03 \mathrm{M}$ & $07.00 \%$ \\
\hline 15 & $\sqrt{ }$ & $\sqrt{ }$ & $\sqrt{ }$ & $\sqrt{ }$ & $\sqrt{ }$ & $0.05 \mathrm{M}$ & $08.25 \%$ \\
\hline 16 & $\sqrt{ }$ & $X$ & $\sqrt{ }$ & $\mathrm{X}$ & $\sqrt{ }$ & $0.07 \mathrm{M}$ & $09.25 \%$ \\
\hline
\end{tabular}

